\title{
SCIDiC
}

\author{
International Journal of Dentistry and Oral Science (IJDOS) \\ ISSN: 2377-8075
}

\section{Evaluation Of Root Reinforcement Potential Of Different Intraorifice Barriers In Gutta Percha Obturated Root Canals - An In Vitro Study}

Research Article

Nandini Biradar ${ }^{1 *}$, Simran Ahluwalia ${ }^{2}$, Nithin Kumar Shetty ${ }^{3}$

${ }^{1}$ Associate Professor, Department of Dentistry, Bidar Institute of Medical Sciences, Bidar, Karnataka-585401, India.

${ }^{2}$ Department of Conservative and Endodontics, Sunshine SpecialityDental Care, Melbourne, Victoria - 3020 Australia.

${ }^{3}$ Assistant Professor, Faculty of Dental science, Ramaiah University of Applied Science Bangalore-560054, India.

\section{Abstract}

Introduction: The aim of the present study was to evaluate the efficiency of different intraorifice barriers in providing fracture resistance to endodontically treated roots.

Methods: Sixty extracted human mandibular teeth instrumented by crown down technique with Protaper rotary files and obturated Gutta-Percha and AH resin sealer. Coronal $3 \mathrm{~mm}$ of gutta percha was removed with the aid of Peeso reamers. The specimens were sub grouped into 4 groups of 15 teeth in each group. Mineral Trioxide Aggregate, Resin Modified Glass Ionomer Cement, Composite were used to fill the space. The force necessary to fracture each root was recorded by using Universal Testing Machine. The results were analyzed by one way Analysis of Variance and pairwise by Student's t-test.

Results: Composite and Resin Modified Glass Ionomer Cement group showed higher fracture resistance, but the differencewas not statistically significant. Mineral trioxide group showed an increase in fracture resistance of teeth but was statistically less significant when compared to Composite and Resin Modified Glass Ionomer groups.

Conclusion: Reinforcement of obturated roots with Composite, Resin Modified Glass Ionomer Cement and Mineral Trioxide Aggregate as intraorifice barriers is a viable choice to reduce the occurrence of post endodontic root fracture.

Keywords: Intra Orifice Barriers; Root Canal; Reinforcement.

\section{Introduction}

Prognosis in Endodontic is dependant on several factors. Complete removal of microorganism by efficient biomechanical preparation and creating three dimensional hermetic seal with an obturating material thereby preventing leakage of fluids from oral cavity to periapical tissues by restoring the tooth with a material which strengthens the remaining tooth structure to with stand masticatory forces [1-4].

Of the various techniques in biomechanical preparation crowndown technique using rotary instruments is commonly used. It reduces cervical interferences, thereby allowing easy and free movement of instruments. This allows lowering the torque on the canal walls and also preventing the building up stresses on the file in the apical region [5]. Furthermore cervical flaring facilitates working length determination [6]. At the same timebecause of cervical flaring there is a notable reduction of the residual dentin thickness (RDT) thereby increasing the chance of vertical root fractures [7]. Hence RDT could be detrimental infracture resistance of tooth [8].

The modulus of elasticity of dentin is 14-16 giga pascals and to limit stress concentrations and to strengthen the roots a material of a similar value should be preferred at dentin material interface [9]. The most commonly materials like resilon despite having higher flexural modulus than Gutta-percha didn't reinforce roots [10].

Role of Coronal restoration is eminent in preventing the movement of microorganisms or toxins into the root canal filling or into the peri apical tissues [11]. No root canal sealer-cement or

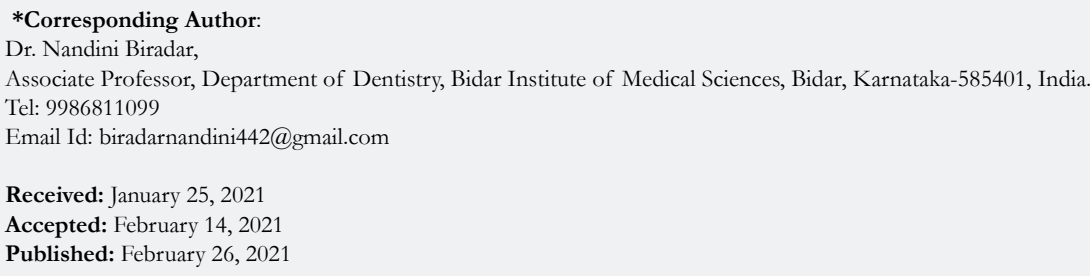

Copyright: Nandini Biradar ${ }^{\circ}$ 2021. This is an open-access article distributed under the terms of the Creative Commons Attribution License, which permits unrestricted use, distribution and reproduction in any medium, provided the original author and source are credited. 
obturation technique completely prevents leakage through the canal, hence newer materials or techniques are being studied [12].

One approach to improving the coronal seal has been to place an additional layer of restorative material, or a double seal directly into the orifices of the root canals as an Intraorifice barrier [12]. Hence intraorifice barriers should not only prevent coronal microleakage but also reinforce the strength to resist root fracture [13].

Several materials have been used in an attempt to provide an intra-coronal seal to prevent microleakage, such as, amalgam, intermediate restorative material, Super-EBA, composite resin, glassionomer cement, and mineral trioxide aggregate [14-18].

Both Composites and resin modified glass ionomer cement are known to have high flexural strength and high modulus of elasticity.The elastic moduli values are similar to dentin and withstand stress [19-21].

MTA as an intracanal medicament wasable to prevent microleakage. The setting reaction includes formation of apatite crystals within the collagen [22].

Hence these three materials were evaluated in this study. Various methods have been used such as Photoelastic studies, 3-dimensional finite element analysis, to test for the fracture resistance of teeth but the compressive load applied along the long axis of the tooth by the Universal Testing Machine used in this study transmits the forces uniformly $[23,24]$.

Therefore, the purpose of the present study is to evaluate the root reinforcement potential of the three different intraorifice barriers placed over gutta percha obturated root canals by using a Universal Testing Machine.

\section{Methods}

Sixty freshly extracted human mandibular premolars needed for this institutionally approved study and these were obtained from patients undergoing tooth extraction for orthodontic purposes. Informed consent was taken from all the patients before extraction. The specimens were selected based on their macroscopically similar size and straight roots. The mesio-distal and bucco-lingual diameters were standardized by using a digital caliper. The mean mesiodistal and buccolingual dimensions were obtained as 7.5 and $8.5 \mathrm{~mm}$ respectively. Roots presenting with less than $\pm 10 \%$ difference from those values were used. They were cleaned and stored in $10 \%$ Formalin. Thereafter, all the specimens were examined under a surgical microscope to ensure absence of cracks.

\section{Specimen Preparation}

The crowns of all sixty mandibular premolar teeth were decoronated using a diamond disc mounted on a straight micro-motor hand piece. The root length was standardized to $14 \mathrm{~mm}$. Pulpal remnants were removed by barbed broaches. With a no.10 K-file patency of canal is checked by passing until it reaches apical foramen and it should be visible. Working length is kept $1 \mathrm{~mm}$ short of apical foramen. The biomechanical preparation was done with Protaper Rotary files (Dentsply) in the following sequence of
Sx,S1,S2,F1,F2 and F3 according to the manufacturer's instructions in conjunction with $15 \%$ Ethylenediaminetetraacetic acid (RC Prep) lubrication and copious irrigation is done with $2 \mathrm{ml}$ of $5.25 \%$ Sodium Hypochlorite irrigation in between. Finally $5 \mathrm{ml}$ of $5.25 \%$ Sodium Hypochlorite is used to flush the canals and dried with paper points.

The specimens were then obturated with gutta percha and resin sealer (AH Plus, Dentsply). The master cone was selected and introduced into the root canal to full working length and was checked for tugback. According to the manufacturer's recommendations AH Plus root canal sealer was mixed in equal volume units (1:1) of Paste A and Paste B on a mixing pad using a metal spatula to a homogeneous consistency. With a K-file in a counter clockwise direction $\mathrm{AH}$ sealer is applied on to the walls of root canal. The master cone was coated with AH-Plus sealer placed into the root canal until the working length was reached. The lateral compaction was done using standardized finger spreaders and accessory GP cones coated with AH-Plus sealer was used.

Except for the control specimens, coronal $3 \mathrm{~mm}$ of root fillings was removed with the aid of Peeso reamers (Easy Post, Dentsply). Microbrushes moistened with alcohol $(70 \%)$ is used to remove remnants of gutta-percha and sealer.

\section{Test groups}

The specimens were randomly subgrouped with respect to the intraorifice barriers material placed over root fillings ( $n=15$ / group):

1. Group A: Mineral Trioxide Aggregate (ProRoot MTA, Dentsply)

2. Group B: Resin Modified Glass Ionomer Cement (Vitremer, 3M ESPE)

3. Group C: Composite (Filtek 250, 3M ESPE)

4. Group D: No Barrier (Control)

\section{Group A: Mineral Trioxide Aggregate (ProRoot MTA, Dent- sply)}

White Mineral Trioxide powder was incorporated into the liquid using a stiff metal spatula on a glass slab for about one minute to ensure all the powder particles were hydrated and mixed into a thick, creamy consistency. It was then placed in the canal using a plastic filling instrument till the material was flush with the sectioned root surface.

Group B: Resin Modified Glass Ionomer Cement ( Vitremer, 3M ESPE) Mixed according to recommended proportion of one scoop powder and one drop of liquid with a cement spatula for 10-15 seconds till all the powder was incorporated into the liquid. The mixed cement had a smooth consistency and glossy appearance. It was then placed in the prepared specimen using a plastic filling instrument and light cured for 30 seconds.

\section{Group C: Composite ( Filtek 250, 3M ESPE)}

Dentin were conditioned with 36\% phosphoric acid for 15 secs. It was then rinsed for 10 secs and excess moisture was blot dried with cotton pellets. Bonding agent was applied using micro brushes and left undisturbed for 20 seconds and gently air dried to 
remove excess solvent for 5 seconds. Light cured for 10 seconds. Increments of Z-250(3M ESPE) were placed. Each increment $(1.5 \mathrm{~mm})$ was light-cured for 40 seconds.

After placement of the intraorifice barrier materials, specimens were stored at $37^{\circ} \mathrm{C}$ and $100 \%$ humidity in distilled water for one week to allow the materials to set completely.

\section{Fracture test:}

With about $9 \mathrm{~mm}$ of each root exposed apical root ends were embedded in self-cure acrylic blocks. Thereafter, the specimens were mounted in a Universal Testing Machine. A steel spherical tip of $2 \mathrm{~mm}$ diameter fixed to the upper arm of the universal testing machine was centered over the canal opening which was set to deliver an increasing load until fracture occurred. Speed of cross head is set to $1 \mathrm{~mm} / \mathrm{min}$ and along axis of the tooth load is applied. Unit of forceneeded for fracture was recorded in Newtons. One-Way ANOVA and Student's t-test were used to determine level of significance between different groups.

\section{Results}

Table 1 shows fracture resistance values of test specimens presented as Mean and Standard deviation.

- In the Control group the values ranged from $342.1 \mathrm{~N}$ to 1568.5 $\mathrm{N}$ with a mean of 891.7.This group demonstrated the least amount of fracture resistance.

- In the MTA group the values ranged from $997.9 \mathrm{~N}$ to $1996.2 \mathrm{~N}$ with a mean of $1,349.20$

- In the RMGIC group the values ranged from 1169.4 N to 3879.6

$\mathrm{N}$ with a mean of $2,498.19$

- In the Composite group the values ranged from $1432.1 \mathrm{~N}$ to $3268.4 \mathrm{~N}$ with a mean of $2,498.19$.

Table 2 shows the parameter was analyzed by One way Analysis of Variance. Due to significance in ANOVA this parameter was further analyzed pairwise by Student's t-test and the $\mathrm{p}$ value- 0.05 was obtained.

- All three groups; MTA, RMGIC and Composite show significantly higher fracture resistance when compared to the Control group.

- Mean difference between MTA and Control: -508.14 with p value- 0.034

- Mean difference between RMGIC and Control- 1358.5667 with $\mathrm{p}$ value $<0.001$

- Mean difference between Composite and Control- 1606.4933 with $\mathrm{p}$ value $<0.001$

- Composite and RMGIC group show significantly higher fracture resistance than MTA group. Mean difference between RMGIC and MTA- 850.4267 with $p$ value $<0.001$ and mean difference between Composite and MTA being 1098.3533 with $p$ value $<0.001$. - Composite and RMGIC groups showed comparable fracture resistance as the difference between their values was statistically insignificant. Mean difference between Composite and RMGIC-247.9267 with p value-0.523.

\section{Discussion}

The fracture resistance of endodontically treated depends on the remaining dentin thickness or tooth structure [25]. The use of irrigating solutions has shown to significantly reduce the microhardness of the dentin can be induced by the use of irrigating solutions during endodontic treatment. The loss of water and gutta-percha condensation procedures may also contribute to the weakness of these teeth $[26,27]$.

Four millimeters above and also apical to the crestal boneis considered to be critical for the tooth to resist fracture. Currently rotary instruments such as Gates Glidden burs, orifice shapers, and profile orificeshaper are commonly used [28]. Isom et al. found that significant amount of dentin is removed at the furcation area while using Gates Glidden burs of no.\#2 and \#3 [29].

Table 1. Fracture Resistance Values (N) of Test Specimens Presented as Mean and Standard Deviation.

\begin{tabular}{|c|c|c|c|c|c|c|c|}
\hline Group & $\mathbf{n}$ & Mean & SD & Median & Min. & Max. & 'p' value \\
\hline Control & 15 & 891.7 & 339.494 & 834.2 & 342.1 & 1568.5 & \\
\cline { 1 - 7 } MTA & 15 & $1,399.84$ & 236.317 & $1,349.20$ & 997.9 & 1996.2 & \multirow{2}{*}{$<0.001$} \\
\cline { 1 - 6 } RMGIC & 15 & $2,250.27$ & 739.038 & $2,438.20$ & 1169.4 & 3879.6 & \\
\cline { 1 - 6 } Composite & 15 & $2,498.19$ & 514.492 & $2,523.40$ & 1432.1 & 3268.4 & \\
\hline
\end{tabular}

Table 2. Fracture Resistance Values Analysis Using One way Analysis of Variance.

\begin{tabular}{|c|c|c|c|c|c|}
\hline \multirow{2}{*}{$\begin{array}{c}\text { (I) } \\
\text { Group }\end{array}$} & \multirow[b]{2}{*}{ (J) Group } & \multirow{2}{*}{$\begin{array}{c}\text { Mean Differ- } \\
\text { ence } \\
\text { (I-J) }\end{array}$} & \multirow[b]{2}{*}{ 'p' value } & \multicolumn{2}{|c|}{$95 \%$ Confidence Interval } \\
\hline & & & & $\begin{array}{l}\text { Lower } \\
\text { Bound }\end{array}$ & $\begin{array}{l}\text { Upper } \\
\text { Bound }\end{array}$ \\
\hline \multirow{3}{*}{ Control } & MTA & -508.14 & 0.034 & -987.201 & -29.079 \\
\hline & RMGIC & -1358.567 & $<0.001$ & -1837.627 & -879.506 \\
\hline & Composite & -1606.493 & $<0.001$ & -2085.554 & -1127.433 \\
\hline \multirow{2}{*}{ MTA } & RMGIC & -850.427 & $<0.001$ & -1329.487 & -371.366 \\
\hline & Composite & -1098.353 & $<0.001$ & -1577.414 & -619.293 \\
\hline RMGIC & Composite & -247.927 & 0.523 & -726.987 & -231.134 \\
\hline
\end{tabular}


Clinicians have long sought to reinforce the remaining tooth structure in order to overcome the reduced fracture resistance of endodontically treated teeth. Gutta percha alongwith an insoluble sealer ideal choice for root obturation [30]. Nevertheless, it has failed to reinforce endodontically treated roots due to its inability to bond to the tooth structure [31]. Apart from gutta percha the other most commonly used obturating material is Resilon. Resilon is composed of a thermoplastic synthetic core containing bioactive glass, bismuth oxychloride, and barium sulfate. It has a dualcuring resin-based sealer [30]. It forms a bond between dentin, sealer and resilon, resulting in a "monoblock" effect between the intraradicular dentin and the root canal filling material [31].

Studies have shown that due to the presence of the monoblockaffect the teeth are resistant to both bacterial leakage and root fracture compared with similar roots that are filled with conventional filling materials $[32,33]$. On the contrary Stuart et al reported no significant differences in reinforcement of endodontically treated roots of immature teeth between Resilon and Gutta-percha when compared with unfilled controls [34]. Added to this Williams et al. reported that the stiffness of Resilon and Guttapercha is not sufficient strengthen roots after root canal therapy [10].

Another parameter which is important for the restorative success is the coronal seal. No matter what the obturation material used the importance of coronal seal has been increasingly recognized in the dental literature. If new microorganisms are allowed to reenter the cleaned and sealed canal space, post-treatment failure can occur.

Prevention of Coronal microleakage isan important factor associated with post endodontic restorations because endodontically treated teeth tend to be more porous thereby creating a path for entry and exit for bacteria and bacterial by-products [35]. Hence post endodontic failure could be because of delay in placing permanent restorative material, fractured coronal restoration, temporary restorative material lacking strength and improper margins for restoration [36].

Permanent restoration is done immediately to prevent coronal microleakage in these teeth. Although a higher success rate has been found in teeth with permanent restorations than in teeth with provisional restorations with regards to coronal microleakage they still showed microleakage when evaluated [37]. Amalgam when used for access restoration showed more coronal leakage than bonded amalgam [38]. Fabricating core build-ups with glass ionomer cements have shown microleakage from dissolution by saliva overtime and composites resins show polymerization shrinkage which is responsible for microleakage [39, 40]. Since the presently available methods have been found to be inadequate in preventing coronal microleakage, the intraorifice barriers were introduced as an additional method to circumvent this problem. An intra-orifice barrier not only can efficiently decrease coronal leakage in endodontically treated teeth by creating a double seal but also proven to reinforce endodontically treated roots preventing fractures $[12,13]$. Hence for an ideal intraorificebarrier it should have workable properties, bond to tooth structure, prevent microleakage, reinforce root, should be able to differentiate from natural tooth structure and doesn't interfere with permanent restoration [41].

Hence the aim of this present study is to evaluate the efficiency of the Intraorifice barriers in preventing coronal microleakage and ability of these to provide stiffness against forces that generate root fractures in endodontically treated teeth.

Inthis study for studying intraorifice barrier $3 \mathrm{~mm}$ of Gutta percha is replaced by a restorative material at the orifice of the root canal. It has several advantages compared to other depths like easy to seal, accommodating bulk of material for retention and can be easy removed for retreatment [42-44].

Various materials have been used as aintraorifice barrier to provide coronal seal [14-18]. The materials evaluated in the study were Composite, Resin Modified Glass ionomer Cement and Mineral trioxide Aggregate.

Various methods have been used to evaluate fracture resistance of teeth under compressive load such as Photoelastic studies, 3-dimensional finite element analysis, but the compressive load applied along the long axis of the tooth by the Instron machine used in this study transmits the forces uniformly [19].

The results of the present study showed that composites and RMGIC significantly increased the fracture resistance of root canal treated teeth as compared to the control and MTA group. The difference between RMGIC and Composite was not statistically significant. This can be attributed to the ability of the restorative materials to bond to the tooth structure bringing about a Monoblock effect meaning 'single unit'. They are classified as primary, secondary, or tertiarymonoblock based on bonding wall and core material [45].

Compositerestoration and RMGIC can be categorized under primary monoblock type and was found to be effective.46 There are conflicting results questioning the ability of bondable materials to form monoblock unit, but the present study is in acceptance with Wilkinson study suggesting the ability of composites strengthen the roots presenting monoblock effect [45, 47, 48]. There was no significant statistical difference in fracture resistance between RMGIC and composite group. This can be attributed to the fact that apart from both being bonded restorations they also have been shown to have high flexural strength and high modulus of elasticity [19, 20]. Both materials are expected to withstand stress and prevent it transmitted to root since elastic modulus are similar to dentin [10]. Observations of this research are similar to the study done to evaluate the reinforcing effect of resin glass ionomer cement in the restoration of immature roots [46].

In addition, RMGIC has shown significant increase in fracture resistance in comparison to MTA and control group. This could be because of chemical bonding to dentin resulting in high adhesive strength [49]. The high adhesive strengthen could be attributed to slow rate acid base reaction resulting in availability of polyacid for longer duration [50].

The study also concluded that MTA significantly strengthened the root filled teeth when compared with the control group. This may be due to it's the elastic modulus $14,000-18,600 \mathrm{MPa}$, which is similar to that of dentin [45]. It could be because of formation of apatite-like interfacial deposits resulting from reaction of calcium and hydroxyl ions released with phosphate ions in dentinal fluid [50]. The results of this study are similar to the previous study showing significantly higher resistance to fracture compared with 
those filled with calcium hydroxide or the controls [51]. Its ability could be because of high stiffness in compression [45].

Results of this study showed that the Mineral trioxide group showed higher fracture resistance when compared to the control but the values were significantly lesser than that of the composite and the resin modified glass ionomer group which could be explained based on the inability of this material to bond to the tooth structure [45] These findings were corroborated by Schmoldt et al who stated that MTA does not reinforce the root when compared with composite resin and fiber post [47].

\section{Conclusion}

The present study concluded that the intraorifice barriers were found to be advantageous in terms of increasing the fracture resistance of endodontically treated teeth. Furthermore, bonded restorations such as Composite and Resin Modified Glass Ionomer Cement have resulted in a higher fracture resistance than non-bonded restorations such as Mineral Trioxide Aggregate. The Instron machine used in the study to fracture the teeth applied non physiological forces to fracture the teeth which warrant the need for better techniques to simulate the forces encountered in the oral environment. Further laboratory research is needed with different materials and better techniques coupled with clinical trials to confirm these results and evaluate their relevance in treatment outcome.Under the conditions of the present ex-vivo evaluation, the following conclusions are drawn:

1. Composite, Resin Modified Glass Ionomer Cement and Mineral Trioxide Aggregate intraorifice barriers Placed over gutta percha obturated root canals had higher fracture resistance compared to that of without intraorifice barriers.

2. Fracture resistance of roots was significantly affected by the type of intraorifice barrier placed. Composite and RMGIC groups showed comparable fracture resistance as the difference between their values was statistically insignificant.

3. Mineral trioxide group also showed an increase in fracture resistance of teeth as compared to the control but the fracture resistance was significantly less than that of Composite and Resin Modified Glass Ionomer groups.

4. Bonded restorations such as Composite and Resin Modified Glass Ionomer cement demonstrated a higher fracture resistance in comparison with Non-bonded restorations like Mineral Trioxide aggregate.

Further laboratory research with different materials and techniques coupled with clinical trials is necessary to validate the results of this in vitro study.

\section{References}

[1]. Orstavik D. Time-course and risk analyses of the development and healing of chronic apical periodontitis in man. IntEndod J. 1996 May;29(3):150-5. Pubmed PMID: 9206419.

[2]. Friedman S. Considerations and concepts of case selection in the management of post-treatment endodontic disease (treatment failure). Endod Topics. 2002 Mar; 1(1):54-78.

[3]. Kirkevang LL, Hørsted-Bindslev P. Technical aspects of treatment in relation to treatment outcome. Endod Topics. 2002 Jul;2(1):89-102.

[4]. Vertucci FJ. Root canal morphology and its relationship to endodontic procedures. Endod Topics. 2005 Mar;10(1):3-29.

[5]. Wu MK, van der Sluis LW, Wesselink PR. The risk of furcal perforation in mandibular molars using Gates-Glidden drills with anticurvature pressure. Oral Surg Oral Med Oral Pathol Oral RadiolEndod. 2005 Mar;99(3):37882.Pubmed PMID: 15716849 .

[6]. Kumar R, Khambete N, Patil S, Hoshing U, Medha A, Shetty R. Working length changes in curved canals after coronal flaring by using rotary files and hand file: An in vitro study. J Conserv Dent. 2013 Sep;16(5):399-403. Pubmed PMID: 24082566.

[7]. Duarte MA, Bernardes RA, Ordinola-Zapata R, Vasconcelos BC, Bramante CM, Moraes IG. Effects of Gates-Glidden, LA Axxess and orifice shaper burs on the cervical dentin thickness and root canal area of mandibular molars. Braz Dent J. 2011;22(1):28-31.Pubmed PMID: 21519644.

[8]. Goto Y, Nicholls JI, Phillips KM, Junge T. Fatigue resistance of endodontically treated teeth restored with three dowel-and-core systems. J Prosthet Dent. 2005 Jan;93(1):45-50.Pubmed PMID: 15623997.

[9]. Marshall SJ, Balooch M, Breunig T, Kinney JH, Tomsia AP, Inai N, et al. Human dentin and the dentin-resin adhesive interface. Acta Mater. 1998 Apr 10;46(7):2529-39.

[10]. Williams C, Loushine RJ, Weller RN, Pashley DH, Tay FR. A comparison of cohesive strength and stiffness of Resilon and gutta-percha. J Endod. 2006 Jun;32(6):553-5.Pubmed PMID: 16728249.

[11]. Bayram HM, Çelikten B, Bayram E, Bozkurt A. Fluid flow evaluation of coronal microleakageintraorifice barrier materials in endodontically treated teeth. Eur J Dent. 2013 Jul;7(3):359-362.Pubmed PMID: 24926217.

[12]. Galvan RR Jr, West LA, Liewehr FR, Pashley DH. Coronal microleakage of five materials used to create an intracoronal seal in endodontically treated teeth. J Endod. 2002 Feb;28(2):59-61.Pubmed PMID: 11833689.

[13]. Nagas E, Uyanik O, Altundasar E, Durmaz V, Cehreli ZC, Vallittu PK, et al. Effect of different intraorifice barriers on the fracture resistance of roots obturated with Resilon or gutta-percha. J. Endod. 2010 Jun 1;36(6):1061-3.

[14]. Maruoka R, Nikaido T, Ikeda M, Foxton R, Tagami J. Effect of resin-coating technique on coronal leakage inhibition in endodontically treated teeth. IntChin J Dent Res. 2007;7:1-6.

[15]. Zakizadeh P, Marshall SJ, Hoover CI, Peters OA, Noblett WC, Gansky SA, et al. A novel approach in assessment of coronal leakage of intraorifice barriers: a saliva leakage and micro-computed tomographic evaluation. J Endod. 2008 Jul;34(7):871-5.Pubmed PMID: 18570999.

[16]. A. Parolia, M. Kundabala, S. Acharya, V. Sarawathi, V. Ballal, and M. Mohan, "Canal systems obturated with gutta-percha," Endodontic Journal, vol. 20, pp. 65-70, 2008.

[17]. Bailón Sánchez M, González Castillo S, González Rodríguez M, PoyatosMartínez R, Ferrer Luque CM. Intraorifice sealing ability of different materials in endodontically treated teeth. Med Oral Patol Oral Cir Bucal.2011;16:e105-e109.

[18]. Jiang QZ, Zhang Q, He J. An evaluation of intra-orifice sealing materials for coronal microleakage in obturated root canals. Chin J Dent Res. 2009 Jun 1;12(1):31-36.

[19]. Xie D, Brantley WA, Culbertson BM, Wang G. Mechanical properties and microstructures of glass-ionomer cements. Dent Mater. 2000 Mar $1 ; 16(2): 129-38$.

[20]. Plotino G, Grande NM, Bedini R, Pameijer CH, Somma F. Flexural properties of endodontic posts and human root dentin. Dent Mater. 2007 Sep;23(9):1129-35.Pubmed PMID: 17116326.

[21]. Gupta A, Arora V, Jha P, Nikhil V, Bansal P. An in vitro comparative evaluation of different intraorifice barriers on the fracture resistance of endodontically treated roots obturated with gutta-percha. J Conserv Dent. $2016 \mathrm{Mar}-$ Apr;19(2):111-5.Pubmed PMID: 27099413.

[22]. Russell AA, Chandler NP, Friedlander LT. Crack Formation Following RootEnd Preparation in Roots with the Butterfly Effect. EurEndod J. 2018 Jul 19;3(2):107-112.Pubmed PMID: 32161865.

[23]. Dietschi D, Duc O, Krejci I, Sadan A. Biomechanical considerations for the restoration of endodontically treated teeth: a systematic review of the literature--Part 1. Composition and micro- and macrostructure alterations. Quintessence Int. 2007 Oct;38(9):733-43.Pubmed PMID: 17873980.

[24]. Dias de Souza GM, Pereira GD, Dias CT, Paulillo LA. Fracture resistance of premolars with bonded class II amalgams. Oper Dent. 2002 JulAug;27(4):349-53.Pubmed PMID: 12120771.

[25]. Clark D, Khademi J. Modern molar endodontic access and directed dentin conservation. Dental Clinics. 2010 Apr 1;54(2):249-73.

[26]. Zaparolli D, Saquy PC, Cruz-Filho AM. Effect of sodium hypochlorite and EDTA irrigation, individually and in alternation, on dentin microhardness at the furcation area of mandibular molars. Braz Dent J. 2012;23(6):654-8. Pubmed PMID: 23338256.

[27]. Goldsmith M, Gulabivala K, Knowles JC. The effect of sodium hypochlorite irrigant concentration on tooth surface strain. J Endod. 2002 Aug;28(8):5759.Pubmed PMID: 12184417.

[28]. Clark D, Khademi JA. Case studies in modern molar endodontic access and directed dentin conservation. Dent Clin North Am. 2010 Apr;54(2):275- 
89.Pubmed PMID: 20433978.

[29]. Isom TL, Marshall JG, Baumgartner JC. Evaluation of root thickness in curved canals after flaring. J Endod. 1995 Jul;21(7):368-71.Pubmed PMID: 7499977.

[30]. Schäfer E, Zandbiglari T, Schäfer J. Influence of resin-based adhesive root canal fillings on the resistance to fracture of endodontically treated roots: an in vitro preliminary study. Oral Surg Oral Med Oral Pathol Oral RadiolEndod. 2007 Feb;103(2):274-9.Pubmed PMID: 17234547.

[31]. Gesi A, Raffaelli O, Goracci C, Pashley DH, Tay FR, Ferrari M. Interfacial strength of Resilon and gutta-percha to intraradicular dentin. J Endod. 2005 Nov;31(11):809-13.Pubmed PMID: 16249724.

[32]. Shipper G, Ørstavik D, Teixeira FB, Trope M. An evaluation of microbial leakage in roots filled with a thermoplastic synthetic polymer-based root canal filling material (Resilon). J Endod. 2004 May;30(5):342-7.Pubmed PMID: 15107647

[33]. Teixeira FB, Teixeira EC, Thompson JY, Trope M. Fracture resistance of roots endodontically treated with a new resin filling material. J Am Dent Assoc. 2004 May;135(5):646-52. doi: 10.14219/jada.archive.2004.0255. Erratum in: J Am Dent Assoc. 2004 Jul;135(7):868.Pubmed PMID: 15202759.

[34]. Stuart CH, Schwartz SA, Beeson TJ. Reinforcement of immature roots with a new resin filling material. J Endod. 2006 Apr;32(4):350-3.Pubmed PMID: 16554210

[35]. Michael Scianamblo .The co-relationship of post-endodontic restorations and endodontic success: rationale and materials. Endodontic Practice 2002;Sept 29-33.

[36]. Tselnik M, Baumgartner JC, Marshall JG. Bacterial leakage with mineral trioxide aggregate or a resin-modified glass ionomer used as a coronal barrier. J Endod. 2004 Nov 1;30(11):782-4

[37]. Safavi KE, Dowden WE, Langeland K. Influence of delayed coronal permanent restoration on endodontic prognosis. Endod Dent Traumatol. 1987 Aug;3(4):187-91.Pubmed PMID: 3481569.

[38]. Kurtzman GM. Improving endodontic success through coronal leakage prevention. Inside Dent. 2005;12:62-7.

[39]. Kleitches AJ, Lemon RR, Jeansonne BG. Coronal microleakage in conservatively restored endodontic access preparations. J Tenn Dent Assoc. 1995 Jan;75(1):31-4.Pubmed PMID: 9520778.

[40]. Bogra P, Gupta S, Kumar S. Comparative evaluation of microleakage in class
II cavities restored with Ceram X and Filtek P-90: An in vitro study. ContempClin Dent. 2012 Jan;3(1):9-14.Pubmed PMID: 22557890.

[41]. Wolcott JF, Hicks ML, Himel VT. Evaluation of pigmented intraorifice barriers in endodontically treated teeth. J Endod. 1999 Sep;25(9):589-92.Pubmed PMID: 10687533.

[42]. Maloney SM, McClanahan SB, Goodell GG. The effect of thermocycling on a colored glass ionomerintracoronal barrier. J Endod. 2005 Jul;31(7):526-8. Pubmed PMID: 15980714.

[43]. Yamauchi S, Shipper G, Buttke T, Yamauchi M, Trope M. Effect of orifice plugs on periapical inflammation in dogs. J Endod. 2006 Jun;32(6):524-6. Pubmed PMID: 16728242.

[44]. Jenkins S, Kulild J, Williams K, Lyons W, Lee C. Sealing ability of three materials in the orifice of root canal systems obturated with gutta-percha. J Endod. 2006 Mar;32(3):225-7.Pubmed PMID: 16500232.

[45]. Tay FR, Pashley DH. Monoblocks in root canals: a hypothetical or a tangible goal. J. Endod. 2007 Apr 1;33(4):391-8.

[46]. Goldberg F, Kaplan A, Roitman M, Manfré S, Picca M. Reinforcing effect of a resin glass ionomer in the restoration of immature roots in vitro. Dent Traumatol. 2002 Apr;18(2):70-2.Pubmed PMID: 12184214.

[47]. Schmoldt SJ, Kirkpatrick TC, Rutledge RE, Yaccino JM. Reinforcement of simulated immature roots restored with composite resin, mineral trioxide aggregate, gutta-percha, or a fiber post after thermocycling. J Endod. 2011 Oct;37(10):1390-3.Pubmed PMID: 21924188.

[48]. Wilkinson KL, Beeson TJ, Kirkpatrick TC. Fracture resistance of simulated immature teeth filled with resilon, gutta-percha, or composite. J Endod. 2007 Apr 1;33(4):480-3

[49]. Mitra SB. Adhesion to dentin and physical properties of a light-cured glassionomer liner/base. J Dent Res. 1991 Jan;70(1):72-4.Pubmed PMID: 1991864.

[50]. Wilson AD. Resin-modified glass ionomer cements. Int J Prosthodont1990;3:425-429.Wilson AD. Resin-modified glass-ionomer cements. Int J Prosthodont1990 Sep 1;3:425-429.

[51]. Andreasen JO, Munksgaard EC, Bakland LK. Comparison of fracture resistance in root canals of immature sheep teeth after filling with calcium hydroxide or MTA. Dent Traumatol. 2006 Jun;22(3):154-6. 